\title{
Presentation, management, and outcomes of STEMI in Egypt: results from the European Society of Cardiology Registry on ST elevation myocardial infarction
}

Sameh Shaheen ${ }^{1 *}$ D, Ahmad Wafa ${ }^{2}$, Mostafa Mokarab ${ }^{3}$, Basem Zareef ${ }^{4}$, Ahmed Bendary $^{5}$, Tarek Abdelhameed ${ }^{6}$, Ahmad Rashwan ${ }^{7}$, Mohamad Seleem ${ }^{8}$, Magdy Elmasry ${ }^{9}$, Yaser Abdelhady ${ }^{10}$, Gomaa Abdelrazik ${ }^{11}$, Amr Ibrahim ${ }^{12}$, Mohamad Ghareeb ${ }^{13}$, Khalid Aly ${ }^{1}$, Mahmoud Saraya ${ }^{14}$, Moheb Wadie $^{2}$ and Mahmoud Youssef ${ }^{2}$

\begin{abstract}
Background: Apart from few small single-center studies, there are limited data about STEMI patients in Egypt. Nineteen Egyptian centers (with and without PCI facilities) participated in this registry with 1356 patients who were compared to 7420 patients from other ESC countries. The aims of this study were to describe the characteristics of patients with STEMI, to assess STEMI management patterns particularly the current use of reperfusion therapies, to evaluate the organization of STEMI networks across Egypt, to evaluate in-hospital patient outcome, and to compare Egyptian patients with other ESC countries.

Results: Compared to other ESC countries, Egyptian patients were younger (mean age $55.4 \pm 11.3$ vs. $62.9 \pm 12.4 ; p$ $<0.001$ and $4.36 \%$ vs. $19.41 \% \%$ were $\geq 75$ years old; $p<0.001)$ with fewer females $(18.44 \%$ vs. $25.63 \% ; p<0.001)$. Egypt had longer median time between symptoms onset and first medical contact: 120.0 (60.0; 240.0) vs.100.0 (50.0; 240.0) $p<0.001$. Self-presentation rather than EMS presentation was the mode of admission in $86.06 \%$ in Egypt vs. $25.83 \%$ in EU countries ( $p$ < 0.001). On qualifying ECG, anterior STEMI was in 57.08\% in Egypt vs. $45.98 \%$ in other countries $(p<0.001$ ). Initial reperfusion therapy was $49.12 \%, 43.07 \%$, and $7.26 \%$ for primary PCl, thrombolytic therapy and no reperfusion in Egypt vs. $85.42 \%, 7.26 \%$, and $7.82 \%$ for EU countries, respectively. In-hospital mortality was $4.65 \%$ in Egypt vs. $3.50 \%$ in other countries $p 0.040$ and was $18.87 \%$ in no reperfusion vs. $2.10 \%$ in primary PCl vs. $4.97 \%$ in thrombolysis $(p<0.001)$ among Egyptians. Patients were discharged on aspirin in $98.61 \%$, clopidogrel in $91.07 \%$, ticagrelor in $7.31 \%$, DAPT in $97.69 \%$, beta blockers in $82.83 \%$, ACE inhibitors in $84.76 \%$, MRAs in $10.01 \%$, and statins in $99.77 \%$.

Conclusion: Compared to other ESC countries, Egyptian STEMI patients were younger, more frequently current smokers and diabetics, and had longer time between symptoms onset and first medical contact with more selfpresentation rather than EMS presentation. Thrombolytic therapy is still a common reperfusion therapy in Egypt while primary PCI was offered to half of the patients. In-hospital mortality was significantly higher in Egypt and was highest among no reperfusion patients and lowest among PPCI patients.
\end{abstract}

Keywords: STEMI, Registry, Egypt, Primary PCI, Thrombolytic, Reperfusion, Networks

\footnotetext{
* Correspondence: samehshaheen@gmail.com

${ }^{1}$ Cardiology Department, Ain Shams University Hospitals, Ain Shams University,

Cairo, Egypt

Full list of author information is available at the end of the article
}

\section{Springer Open}

(c) The Author(s). 2020 Open Access This article is licensed under a Creative Commons Attribution 4.0 International License, which permits use, sharing, adaptation, distribution and reproduction in any medium or format, as long as you give appropriate credit to the original author(s) and the source, provide a link to the Creative Commons licence, and indicate if changes were made. The images or other third party material in this article are included in the article's Creative Commons licence, unless indicated otherwise in a credit line to the material. If material is not included in the article's Creative Commons licence and your intended use is not permitted by statutory regulation or exceeds the permitted use, you will need to obtain permission directly from the copyright holder. To view a copy of this licence, visit http://creativecommons.org/licenses/by/4.0/. 


\section{Background}

Mortality due to CVD in Egypt is one of the highest compared to other countries in the region and worldwide [1].

Apart from a small number of single center studies there are limited descriptive data about STEMI patients in Egypt [2-4]. The lack of data on the clinical characteristics of patients, hospital practice, and treatment patterns as well as the impact of management on outcomes for STEMI in Egypt underscore the need for a national registry database.

\section{Methods}

The European Society of Cardiology ACCA-EAPCI Registry on ST elevation myocardial infarction is a Joint initiative of the Acute Cardiovascular Care Association (ACCA) and the European Association of Percutaneous Cardiovascular Interventions (EAPCI) of the European Society of Cardiology. It is a registry to evaluate the treatment of STEMI across Europe and the Mediterranean countries. It is a general, prospective, multicenter, and observational registry. The ESC-STEMI registry study design has been described in detail in a recent publication [5].

The EURObservational Research Programme (EORP) department at the European Heart House coordinated the project operationally, provided support to the participating centers, and guided the methodological aspects of the survey. The database was stored and analyzed at the European Heart House.

The Egyptian society of cardiology, being a member of the ESC, participated in this registry with data from 19 Egyptian centers. Site selection aimed at centers of different levels of complexity and in different geographic regions in order to obtain a sample representative of Egyptian population. Onsite PCI capability was present in $15 / 17$ centers $(88.24 \%)$, onsite cardiac surgery in 11 / 17 centers $(64.71 \%)$, and $8 / 16(50.00 \%)$ reported that primary PCI was their usual treatment for STEMI patients. The median number (Q1; Q3) of beds in these centers was 91.5 (35.0; 325.0), MI volume/year was 500.0 (250.0; $720.0)$, total PCI/year was 800.0 (400.0; 2000.0), and total primary PCI was 220.0 (90.0; 350.0). Local audits were performed in randomly selected centers to check compliance with the protocol and review consecutiveness and quality of data.

The target population was patients with chest pain or equivalent symptoms of more than 20 min duration within the last $24 \mathrm{~h}$ prior to admission to hospital and ST segment elevations or LBBB in the diagnostic ECG. Each center was asked to enroll up to 60 consecutive patients. Egypt participated with 1356 (15.45\%) patients who will be compared with 7420 patients from other EU or Mediterranean countries. Patient recruitment started from March 2016 to February 2018.

The aims of this study were to describe the demographic, clinical, and biological characteristics of patients with STEMI admitted to a representative setting of cardiology centers in EGYPT, to assess the organization of STEMI management across Egypt, to evaluate how STEMI ESC guidelines were adopted, to evaluate inhospital patient outcome, and to compare Egyptian patients with those from other participating countries.

Continuous variables were reported in means (standard deviation) or as median and interquartile range (IQR) when skewed. Categorical variables were reported as percentages and compared using the $\chi^{2}$ test. Continuous variables were compared by the Mann-Whitney $U$ test. Kruskal-Wallis test was used when more than two groups were compared. A $p$ value of $<0.05$ was considered statistically significant. All tests were two-sided.

\section{Results}

Patients' characteristics: Table 1

Compared to other countries, Egyptian patients were younger (mean age $55.4 \pm 11.3$ vs. $62.9 \pm 12.4 ; p$ value < 0.001 and patients $\geq 75$ years old were $4.36 \%$ vs. $19.41 \%$; $p$ value $<0.001)$ with fewer females $(18.44 \%$ vs. $25.63 \%$; $p$ value $<0.001)$. Furthermore, fewer Egyptian patients had history of myocardial infarction ( $7.95 \%$ vs. $12.66 \%$; $p$ value $<0.001)$, chronic heart failure $(2.07 \%$ vs. $11.51 \%$; $p$ value $<0.001)$, Stroke/TIA $(3.99 \%$ vs. $5.55 \% p$ value $0.018)$, PCI $(7.10 \%$ vs. $10.43 \% p$ value $<0.001)$, CABG (0.81\% vs. $1.52 \% p$ value 0.043$)$, atrial fibrillation $(1.55 \%$ vs. $5.32 \% p$ value $<0.001)$, peripheral vascular disease $(0.89 \%$ vs. $5.89 \% p$ value $<0.001)$, and malignancy $(0.67 \%$ vs. $2.60 \%, p$ value $<0.001)$ but no significant difference for patients on dialysis $(0.44 \%$ vs. $0.26 \% p$ value $0.265)$. On the other hand, Egyptian patients had higher prevalence of traditional risk factors such as current smoking (59.05\% vs. 42.81\%; $p$ value $<0.001)$, diabetes mellitus (40.79\% vs. $21.95 \%, p$ value $<0.001)$, BMI $\geq 30$ $\mathrm{kg} / \mathrm{m}$ (34.34\% vs. $25.90 \%$; $p$ value $<0.001)$, LDL cholesterol $(\mathrm{mg} / \mathrm{dL})(134.8 \pm 43.1$ vs. $112.4 \pm 40.3 ; p$ value < $0.001)$, plasma glucose $(\mathrm{mg} / \mathrm{dL})(180.8 \pm 80.2$ vs. $143.6 \pm$ $67.0 ; p$ value $<0.001)$ but less history of hypertension $(37.23 \%$ vs. $52.65 \%, p$ value $<0.001)$

\section{Hospital admission process (Fig. 1)}

Median time (Q1; Q3) in minutes between symptoms onset and call for medical help in Egypt was 85.0 (30.0; $210.0)$ vs. $74.5(30.0 ; 210.0)$ in other countries ( $p$ value 0.039 ) while the median time between symptoms onset and first medical contact was $120.0(60.0 ; 240.0)$ vs.100.0 (50.0; 240.0) ( $p$ value < 0.001). In Egypt, compared to other countries, ER staff was the first medical contact $(81.42 \%$ vs. $24.62 \% ; p$ value $<0.001)$, self-presentation 
Table 1 Patients baseline clinical characteristics; Egypt vs. other ESC countries

\begin{tabular}{llll}
\hline & $\begin{array}{l}\text { Egypt } \\
(n=1356)\end{array}$ & $\begin{array}{l}\text { Other ESC countries } \\
(n=7420)\end{array}$ & $p$ value \\
\hline Age (years) median (Q1; Q3) & $55.0(48.0 ; 63.0)$ & $62.0(54.0 ; 71.0)$ & $<0.001(\mathrm{~S})$ \\
Age $\geq 75$ years & $59 / 1354(4.36 \%)$ & $1433 / 7381(19.41 \%)$ & $<0.001(\mathrm{~S})$ \\
Female & $250 / 1356(18.44 \%)$ & $1902 / 7420(25.63 \%)$ & $<0.001(\mathrm{~S})$ \\
BMI $\geq 30 \mathrm{~kg} / \mathrm{m}^{2}$ & $444 / 1293(34.34 \%)$ & $1809 / 6984(25.90 \%)$ & $<0.001(\mathrm{~S})$ \\
Previous myocardial infarction & $107 / 1346(7.95 \%)$ & $865 / 6830(12.66 \%)$ & $<0.001(\mathrm{~S})$ \\
Previous angina & $303 / 1345(22.53 \%)$ & $1645 / 6746(24.38 \%)$ & $<.146(\mathrm{NS})$ \\
Chronic heart failure & $28 / 1350(2.07 \%)$ & $838 / 7283(11.51 \%)$ & $<0.001(\mathrm{~S})$ \\
Previous stroke/TIA & $54 / 1354(3.99 \%)$ & $409 / 7367(5.55 \%)$ & $0.018(\mathrm{~S})$ \\
Previous PCl & $96 / 1353(7.10 \%)$ & $769 / 7370(10.43 \%)$ & $<0.001(\mathrm{~S})$ \\
Previous CABG & $11 / 1355(0.81 \%)$ & $112 / 7389(1.52 \%)$ & $<.043(\mathrm{~S})$ \\
Atrial fibrillation & $21 / 1355(1.55 \%)$ & $392 / 7366(5.32 \%)$ & $<0.001(\mathrm{~S})$ \\
Peripheral vascular disease & $12 / 1342(0.89 \%)$ & $411 / 6979(5.89 \%)$ & $<0.001(\mathrm{~S})$ \\
Current smoker & $799 / 1353(59.05 \%)$ & $3097 / 7234(42.81 \%)$ & $<0.001(\mathrm{~S})$ \\
Diabetes mellitus & $547 / 1341(40.79 \%)$ & $1615 / 7357(21.95 \%)$ & $<0.001(\mathrm{~S})$ \\
Hypercholesterolemia & $141 / 1111(12.69 \%)$ & $2848 / 6333(44.97 \%)$ & $<0.001(\mathrm{~S})$ \\
Treated hypertension & $503 / 1351(37.23 \%)$ & $3833 / 7280(52.65 \%)$ & $<0.001(\mathrm{~S})$ \\
\hline
\end{tabular}

was the mode of admission (86.06\% vs. 25.83\%; $p$ value < 0.001 ) and a non PCI capable center was the first hospital receiving STEMI patients $(42.04 \%$ vs. $26.99 \% ; p$ value $<0.001$ )

\section{Patient presentation and initial assessment (Table 2)}

Patients admitted after an out of hospital cardiac arrest in Egypt was $2.51 \%$ vs. $5.49 \%$ in EU countries $p$ value < 0.001 . On qualifying ECG, anterior STEMI was in $57.08 \%$ in Egypt vs. $45.98 \%$ in other countries ( $p$ value < 0.001 ), atrial fibrillation was in $3.47 \%$ vs. $6.20 \%$ ( $p$ value $<0.001)$, and heart rate (mean $\pm \mathrm{SD}$ ) was $84.8 \pm 19.4 \mathrm{vs}$. $78.4 \pm 19.6$ ( $p$ value $<0.001$ ). Killip class IV was in $2.88 \%$ in Egypt vs. $4.27 \%$ in other countries ( $p$ value <

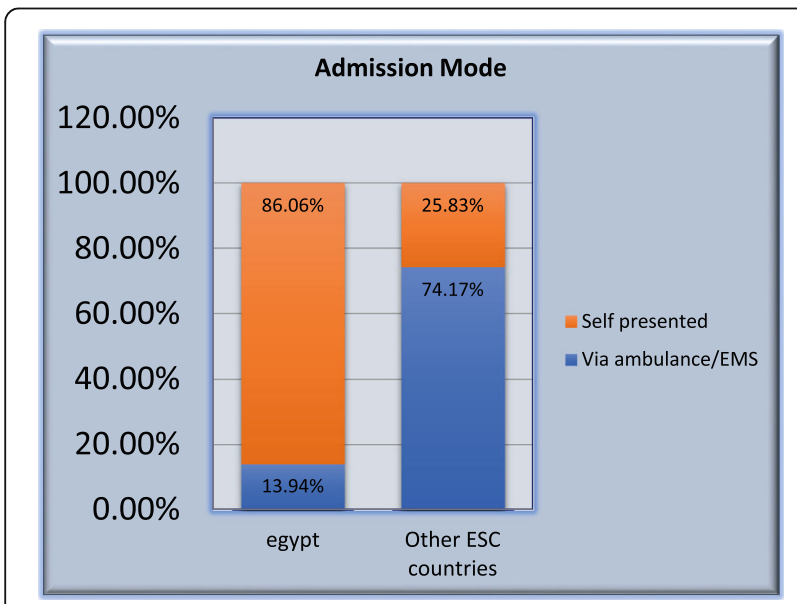

Fig. 1 Admission mode in Egypt vs. other countries
0.001), mechanical ventilation was used in $4.06 \%$ in Egypt vs. $5.67 \%$ in other countries ( $p$ value 0.016 ), therapeutic hypothermia was used in $1.40 \%$ in Egypt vs. $2.14 \%$ in other countries ( $p$ value 0.078), and therapeutic hypothermia when used was external cooling pads/blankets/wraps in $100.00 \%$ in Egypt vs. $11.41 \%$ in other countries ( $p$ value $<0.001)$.

\section{STEMI reperfusion pattern (Fig. 2)}

Intended treatment for STEMI in Egypt vs. other countries was primary $\mathrm{PCI}$ in $50.59 \%$ vs. $85.50 \%$, thrombolysis in $43.14 \%$ vs. $5.55 \%$, and no reperfusion in $6.05 \%$ vs. 4.72\%. Actual initial reperfusion in Egypt vs. other countries: primary PCI in $49.12 \%$ vs. $85.42 \%$, thrombolytic therapy $43.07 \%$ vs.7.26\% and no reperfusion in $7.82 \%$ vs.7.32\%. Thrombolysis was given in the CCU/ICU rather than EMS or ER in $97.26 \%$ in Egypt vs.43.77\% in other countries.

Intended treatment for STEMI in Egypt vs. other countries was primary PCI in $50.59 \%$ vs. $85.50 \%$, thrombolysis in $43.14 \%$ vs. $5.55 \%$, and no reperfusion in $6.05 \%$ vs. $4.72 \%$. Actual initial reperfusion in Egypt vs. other countries: primary PCI in $49.12 \%$ vs. $85.42 \%$, thrombolytic therapy $43.07 \%$ vs.7.26\% and no reperfusion in $7.32 \%$ vs.7.82\%. Thrombolysis was given in the CCU/ICU rather than EMS or ER in $97.26 \%$ in Egypt vs. $43.77 \%$ in other countries.

\section{Complications during hospitalization (Table 3)}

Compared to thrombolytic therapy, patients who were treated with primary $\mathrm{PCI}$ had less incidence of 
Table 2 Presentation and initial assessment; Egypt vs. other countries

\begin{tabular}{|c|c|c|c|}
\hline & $\begin{array}{l}\text { Egypt } \\
(n=1356)\end{array}$ & $\begin{array}{l}\text { other countries } \\
(n=7420)\end{array}$ & $p$ value \\
\hline Anterior STEMI on qualifying ECG & $774 / 1356(57.08 \%)$ & $3205 / 6971$ (45.98\%) & $<0.001(\mathrm{~S}) \dagger$ \\
\hline AF on qualifying ECG & $47 / 1356(3.47 \%)$ & $460 / 7420(6.20 \%)$ & $<0.001(\mathrm{~S})$ \\
\hline $\begin{array}{l}\text { HR on qualifying ECG } \\
\text { median (Q1; Q3) }\end{array}$ & $85.0(70.0 ; 100.0)$ & $77.0(65.0 ; 90.0)$ & $<0.001(S)$ \\
\hline $\begin{array}{l}\text { SBP at first presentation } \\
\text { median }(\mathrm{Q} 1 ; \text { Q3) }\end{array}$ & $120.0(110.0 ; 140.0)$ & $135.0(120.0 ; 150.0)$ & $<0.001(\mathrm{~S})$ \\
\hline Killip class IV at first presentation & $39 / 1356(2.88 \%)$ & $316 / 7397(4.27 \%)$ & $<0.001(\mathrm{~S})$ \\
\hline $\begin{array}{l}\mathrm{LDL} \text { cholesterol }(\mathrm{mg} / \mathrm{dL}) \\
\text { mean }( \pm \text { Std })\end{array}$ & $134.8( \pm 43.1)$ & $112.4( \pm 40.3)$ & $<0.001(\mathrm{~S})$ \\
\hline Glucose plasma level $(\mathrm{mg} / \mathrm{dL})$ mean $( \pm \mathrm{Std})$ & $180.8( \pm 80.2)$ & $143.6( \pm 67.0)$ & $<0.001(\mathrm{~S})$ \\
\hline
\end{tabular}

cerebrovascular accident $(0.75 \%$ vs. $1.37 \% ; p$ value < $0.001)$, heart failure $(9.46 \%$ vs. $10.79 \%$; $p$ value $<0.001)$; Killip class IV (3.00\% vs. $5.99 \%$; $p$ value $<0.001)$, atrial fibrillation $(2.55 \%$ vs. $3.60 \%$; $p$ value 0.008$)$; and no difference in mechanical complications $(0.45 \%$ vs. $0.34 \% ; p$ value 1.000). On the other hand, primary PCI had higher definite stent thrombosis $(1.36 \%$ vs. $0.00 \%)$ and most serious bleeding (5.71\% vs. $3.25 \%, p$ value 0.042 ).

Compared to other countries, STEMI Egyptian patients had more cerebrovascular accident (1.40\% vs.0.98\%; $p$ value 0.166$)$ but less re-infarction $(0.81 \%$ vs. $1.36 \%$; $p$ value $0.097)$, stent thrombosis $(0.67 \%$ vs. $1.26 \%$; $p$ value < $0.001)$, atrial fibrillation $(3.47 \%$ vs. $9.13 \%$; $p$ value $<0.001$, heart failure $(11.14 \%$ vs. $29.32 \%$; $p$ value $<0.001)$, and higher LVEF before discharge $50.4 \pm 9.6$ vs. $47.4 \pm 10.4 ; p$ value $<0.001$.

In-hospital mortality and status at discharge (Fig. 3)

In-hospital mortality was $4.65 \%$ in Egypt (vs. $3.50 \%$ in other countries; $p$ value 0.040 ): $18.87 \%$ in no-reperfusion Egyptian patients, $2.10 \%$ in primary PCI, $4.97 \%$ in thrombolysis $(p$ value $<0.001)$. Time between symptoms onset and death (minutes) was $2517.6 \pm 3477.2$ in Egypt (vs. $8558.7 \pm 13826.5$ in other countries; $p$ value < $0.001): 1889.5( \pm 2803.3)$ in no-reperfusion, $3701.3 \pm$ 5403.6 in primary PCI, $2379.3 \pm 2623.3$ in thrombolysis; $p=0.532$. Time between first medical contact and death

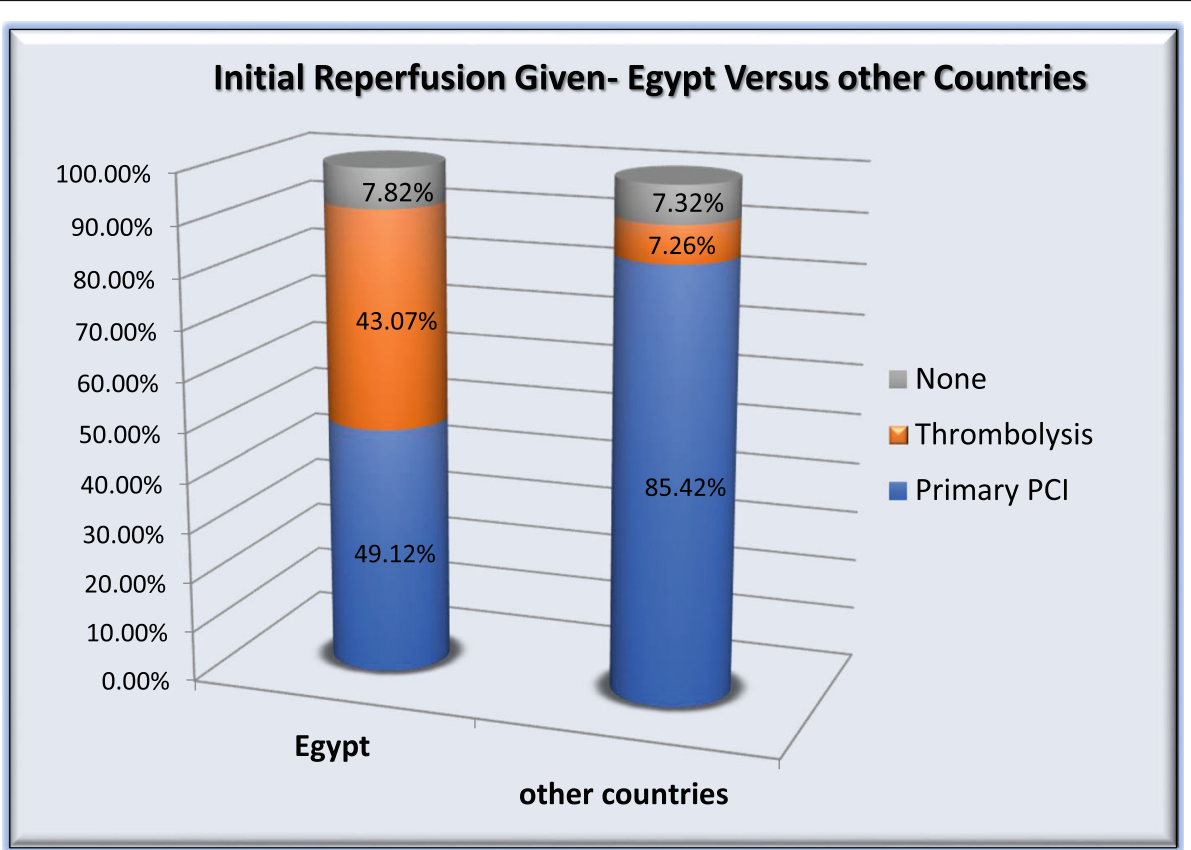

Fig. 2 Initial reperfusion given in Egypt vs. other countries 
Table 3 Patients course during hospitalization; Egypt vs. other countries

\begin{tabular}{|c|c|c|c|}
\hline & $\begin{array}{l}\text { Egypt } \\
(n=1356)\end{array}$ & $\begin{array}{l}\text { Other } \\
\text { countries } \\
(n=7420)\end{array}$ & $p$ value \\
\hline $\begin{array}{l}\text { Last LV ejection fraction } \\
\text { before discharge mean }( \pm \text { Std })\end{array}$ & $50.4( \pm 9.6)$ & $47.4( \pm 10.4)$ & $\begin{array}{l}<0.001 \\
(\mathrm{~S})\end{array}$ \\
\hline Most serious bleeding & $\begin{array}{l}84 / 1356 \\
(6.19 \%)\end{array}$ & $\begin{array}{l}350 / 7414 \\
(4.72 \%)\end{array}$ & $0.001(\mathrm{~S})$ \\
\hline Any transfusion & $\begin{array}{l}6 / 1356 \\
(0.44 \%)\end{array}$ & $\begin{array}{l}115 / 7418 \\
(1.55 \%)\end{array}$ & $0.001(S)$ \\
\hline Cerebrovascular accident & $\begin{array}{l}19 / 1356 \\
(1.40 \%)\end{array}$ & $\begin{array}{l}73 / 7418 \\
(0.98 \%)\end{array}$ & $0.166(\mathrm{NS})$ \\
\hline $\begin{array}{l}\text { Hemorrhagic cerebrovascular } \\
\text { accident }\end{array}$ & $\begin{array}{l}4 / 1356 \\
(0.29 \%)\end{array}$ & $\begin{array}{l}16 / 7418 \\
(0.22 \%)\end{array}$ & 0.460 (NS) \\
\hline Staged PCl & $\begin{array}{l}168 / 1337 \\
(12.57 \%)\end{array}$ & $\begin{array}{l}1481 / 6859 \\
(21.59 \%)\end{array}$ & $\begin{array}{l}< \\
0.001(\mathrm{~S})\end{array}$ \\
\hline CABG & $\begin{array}{l}26 / 1355 \\
(1.92 \%)\end{array}$ & $\begin{array}{l}186 / 7418 \\
(2.51 \%)\end{array}$ & 0.194 (NS) \\
\hline Re-infarction & $\begin{array}{l}11 / 1356 \\
(0.81 \%)\end{array}$ & $\begin{array}{l}101 / 7418 \\
(1.36 \%)\end{array}$ & 0.097 (NS) \\
\hline Definite stent thrombosis & $\begin{array}{l}9 / 1350 \\
(0.67 \%)\end{array}$ & $\begin{array}{l}93 / 7396 \\
(1.26 \%)\end{array}$ & $\begin{array}{l}< \\
0.001(\mathrm{~S})\end{array}$ \\
\hline Mechanical complications & $\begin{array}{l}5 / 1356 \\
(0.37 \%)\end{array}$ & $\begin{array}{l}65 / 7418 \\
(0.88 \%)\end{array}$ & 0.053 (NS) \\
\hline Heart failure & $\begin{array}{l}151 / 1356 \\
(11.14 \%)\end{array}$ & $\begin{array}{l}2043 / 6967 \\
(29.32 \%)\end{array}$ & $\begin{array}{l}< \\
0.001(\mathrm{~S})\end{array}$ \\
\hline Atrial fibrillation & $\begin{array}{l}47 / 1356 \\
(3.47 \%)\end{array}$ & $\begin{array}{l}677 / 7417 \\
(9.13 \%)\end{array}$ & $\begin{array}{l}< \\
0.001(S)\end{array}$ \\
\hline ECG rhythm AF at discharge & $\begin{array}{l}15 / 1293 \\
(1.16 \%)\end{array}$ & $\begin{array}{l}247 / 6700 \\
(3.69 \%)\end{array}$ & $\begin{array}{l}< \\
0.001(\mathrm{~S})\end{array}$ \\
\hline
\end{tabular}

(min) mean \pm SD was $2301.7 \pm 3461.0$ in Egypt (vs. $8273.7 \pm 13767.1$ in other countries; $p$ value < 0.001): $1652.5 \pm 2867.7$ in no-reperfusion, $3477.0 \pm 5303.9$ in primary PCI, $2182.1 \pm 2622.3$ in thrombolysis. Time between arrival at hospital and death or discharge (days) Mean \pm SD was $3.6 \pm 8.9$ in Egypt (vs. $7.2 \pm 7.0$ in other countries, $p$ value $<0.001$ ): $2.9 \pm 2.1$ in no-reperfusion, $3.8 \pm 12.5$ in primary $\mathrm{PCI}, 3.4 \pm 1.8$ in thrombolysis, $p$ value $<0.001$. Percent of patients transferred to other hospitals if discharged alive was $47 / 1293(3.63 \%)$ in Egypt vs. $1069 / 7026(15.21 \%)$ in other countries $p$ value $<0.001$.

\section{Medications (Fig. 4)}

Among Egyptian patients, the following antithrombotic agents were prescribed during first $24 \mathrm{~h}$ after admission: unfractionated heparin in $31.19 \%$, low molecular weight heparin in $72.35 \%$, and fondaparinux in $0.22 \%$. The following medications were prescribed at discharge: aspirin in $98.61 \%$, clopidogrel in $91.07 \%$, ticagrelor in $7.31 \%$ and DAPT in 97.69\%, aspirin and VKA and ADP receptor blockers in $26 / 1299(2.00 \%)$, statins in $99.77 \%$, beta blockers in $82.83 \%$, ACE inhibitors in $84.76 \%$, ARBs in $3.31 \%$, MRAs in $10.01 \%$, digoxin in $0.85 \%$, ivabradine in $6.62 \%$, ezetimibe in $1.92 \%$, and PPIs in $48.96 \%$.

\section{Discussion}

\section{Patients' characteristics}

Egyptian STEMI patients were younger than their counterparts in other countries. This observation has been reported repeatedly in many previous Egyptian studies [4]. This might be due to younger age of the whole Egyptian population, the higher prevalence and poor control of

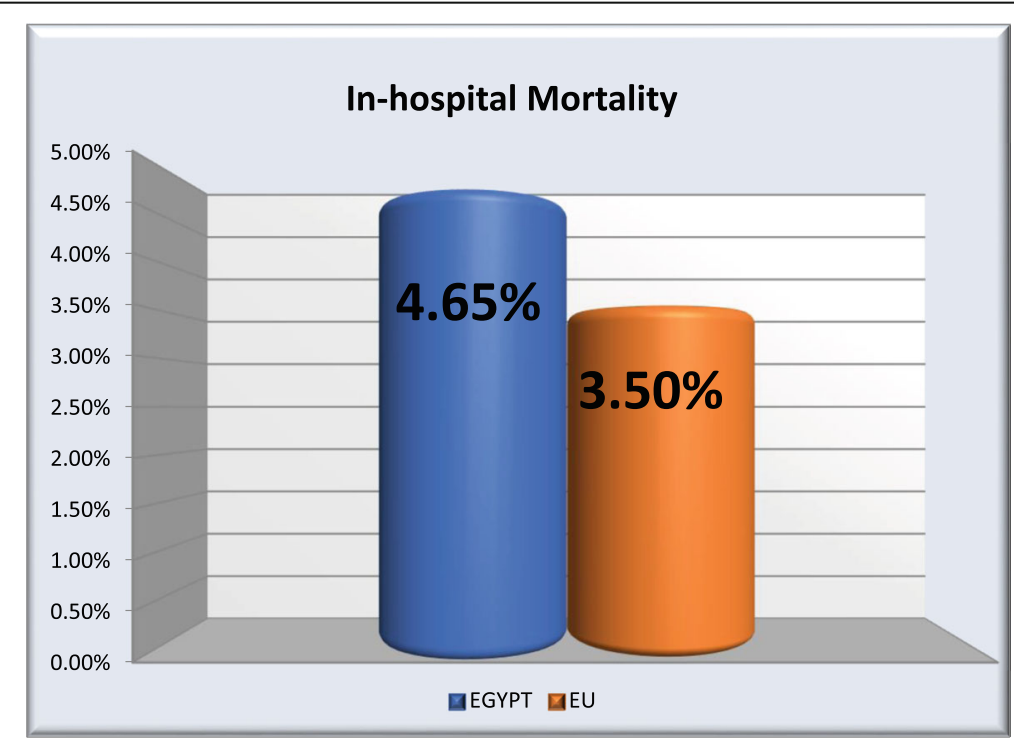

Fig. 3 In-hospital mortality in Egypt vs. other countries 


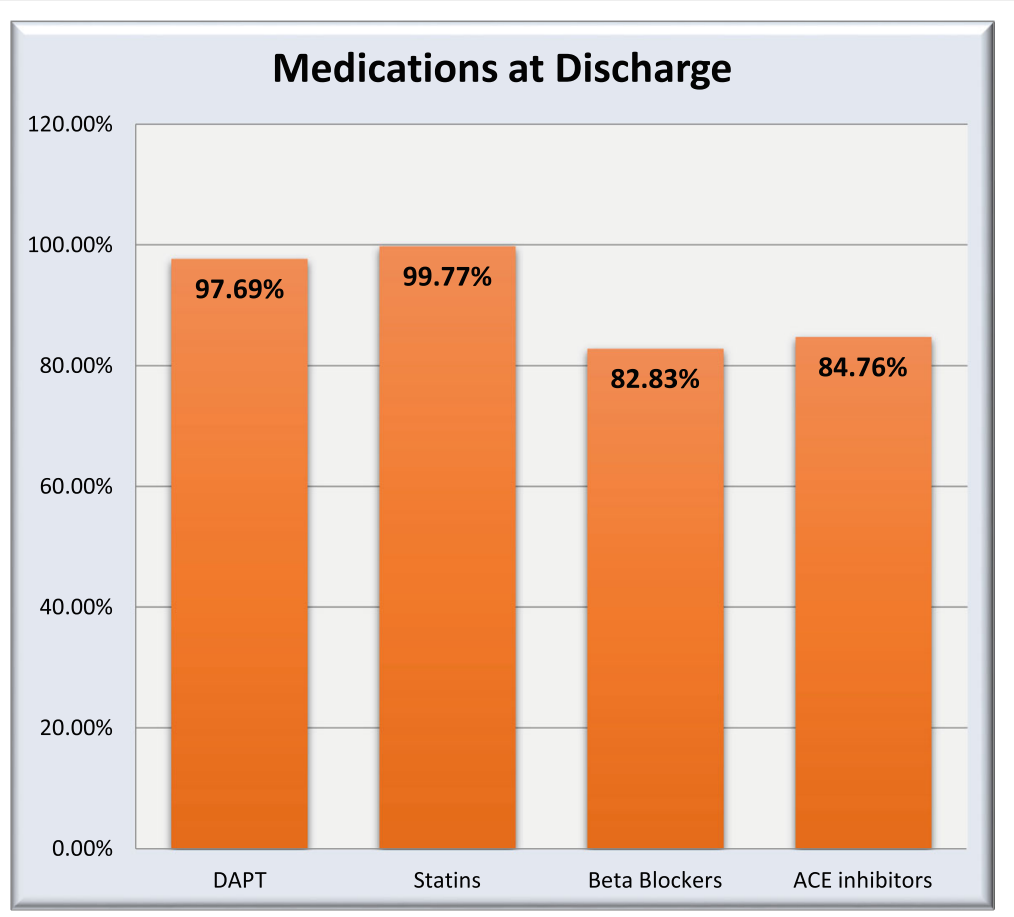

Fig. 4 Medications at discharge among Egyptian patients

risk factors or to a more aggressive nature of atherosclerosis causing earlier coronary artery disease among Egyptians. Reports from India and other developing countries have similar observations [6, 7].

The higher prevalence of traditional risk factors among Egyptian patients highlights the importance of focusing on primary prevention which is as important as treating patients with acute cardiovascular events. Egypt needs a national primary prevention strategic plan to early detect and properly control these risk factors.

\section{Hospital admission process}

EMS service is very much under used among Egyptian patients with STEMI. This very low rate of EMS usage among STEMI patients is similar to the lowest rate among European countries which, in one report, ranged from 18 to $85 \%$ [8].

In this registry, all indicators of out of hospital delay, like the median time between symptoms onset and call for medical help and the median time between symptoms onset and first medical contact, were significantly longer among Egyptian patients. Self-presentation rather than EMS-presentation, having hospital ER rather than the ambulance as the first medical contact, and presenting to a non-PCI capable hospital were potential causes for pre-hospital delay in Egypt [9].

In this registry, the median time in minutes between symptoms onset and call for medical help in Egypt was 85.0 vs. 74.5 in EU countries, while the median time between symptoms onset and first medical contact was 120 vs. 100 min. Among patients treated with primary PCI, the median time from symptom onset to first medical contact ranged from 60 to $210 \mathrm{~min}$, the time between FMC to balloon ranged from 60 to $177 \mathrm{~min}$ while the total ischemic time ranged from 180 to $325 \mathrm{~min}$.

In an older European report, among patients treated with thrombolytic therapy, the median time from symptom onset to first medical contact ranged from 68 to 210 min, the time between FMC to thrombolytic therapy ranged from 30 to $110 \mathrm{~min}$ while the total ischemic time ranged from 113 to $320 \mathrm{~min}$.

In an Egyptian registry, among 137 STEMI patients treated with primary $\mathrm{PCI}$ in a single tertiary center, the mean time of pain to FMC was 378 min while the door to balloon time was $41 \mathrm{~min}$ [10].

Many reports from both developed and developing countries have shown marked improvement (reduction) of total ischemic time and prehospital time delay after adopting national plans to increase patient awareness and to connect cardiac centers and EMS via regional networks [11-14].

\section{Patient presentation and initial assessment}

The lower incidence of out of hospital cardiac arrest in Egypt might be due to either under reporting because of culture issues in Egypt to avoid post mortem investigation and the very low rate of EMS use or a true lower incidence due to younger age and lower risk profile of the Egyptian patients. 
In Egypt, therapeutic hypothermia is not a wellestablished used technique among post-cardiac arrest patients and hypothermia when used was only external cooling pads, blankets, or wraps.

Atrial fibrillation and heart failure were lower among Egyptian patients probably due to the younger age or to under-diagnosis

\section{STEMI reperfusion pattern}

The practice of primary PCI in Egypt has improved along the past decade despite a lot of obstacles mainly limited public medical insurance coverage and limited number of $24 / 7$ cath labs with well trained staff especially in remote Egyptian areas. In a registry of the largest two cardiology centers in Egypt, from 2007 to 2011, only $7.2 \%$ of PCI procedures were for non-elective patients with STEMI and NSTEM [15].

In the Egyptian National heart Institute Registry, among patients with ST-elevation, $65.5 \%$ received streptokinase while only $12.4 \%$ were referred for primary PCI [16]. In a more recent registry, the rate of primary PCI among STEMI patients was $37 \%$ and thrombolysis in $54.7 \%$ [4]. The ACCESS registry, a prospective observational multinational registry, 134 sites in 19 countries in Latin America, middle east, north, and south Africa, 9732 ACS patients with 1 year follow-up, 45\% STEMI and 52\% NSTEMI, STEMI had fibrinolysis in 30\%, and primary PCI in 26\% [17].

The ACCESS registry, a prospective observational multinational registry, 134 sites in 19 countries in Latin America, middle east, north, and south Africa, 9732 ACS patients with 1 year follow-up, 45\% STEMI and $52 \%$ NSTEMI, STEMI had fibrinolysis in 30\% and primary PCI in 26\% [17].

Among 20 European countries, there was large difference in the rate and pattern of STEMI reperfusion: primary PCI ranged from 5 to $92 \%$, thrombolysis ranged from 1 to $55 \%$, and no-reperfusion ranged from 7 to $52 \%$ in some countries. Egypt was not included in that report.

In a more recent report, the rate of primary PCI per 1 million inhabitants ranged from 25 to 884. The recommended figure is $>600$ PPCI per 1 million inhabitants; for Egypt it was 29 per 1 million inhabitants. Egypt short-term target should be 400 PPCI per million, i.e., total of $40000 \mathrm{PPCI} /$ year, i.e., $40 \%$ of the estimated total number of 100,000 STEMI/year [18, 19].

According to a recent report, Egypt has $<10$ interventional cardiologist/million inhabitants compared to Germany which has $\geq 25,<2$ cath labs/million vs. $\geq 5$ in Germany, and $<1$ PPCI cath lab/million vs. $\geq 4$ in Germany. The number of PPCI procedures was $<200$ per million compared to $\geq 600$ in Germany [20].

Non-reperfused patients are mainly those with late presentation beyond the window of reperfusion. Their number was probably under estimated because we included 19 very active centers that apply guidelines recommendations in the diagnosis and management of STEMI patients.

Thrombolysis is still a very common reperfusion method among STEMI patients in Egypt and is mostly given in the ICU/CCU of the hospitals and almost never in the EMS (out of hospital) nor in the ER. The thrombolytic agent given is mostly streptokinase and not TNK or rTPA due to limited resources. Routinely sending patients post thrombolysis to primary PCI within $2-24 \mathrm{~h}$ is generally underused strategy. Egypt should improve all aspects of this mode of reperfusion when applied.

\section{Complications during hospitalization}

The highest incidence of complications was among the non-perfused patients, who had the highest incidence of in-hospital mortality compared to re-perfused patients.

Primary PCI patients had fewer incidences of cerebrovascular accidents heart failure and atrial fibrillation probably due to higher incidence of successful reperfusion while they had higher incidence of serious bleeding (probably related to vascular access site bleeding) and stent thrombosis obviously as stenting is their default treatment.

The higher incidence of cerebrovascular accidents among Egyptian Compared to EU patients is probably due to higher use of thrombolytic therapy among the former. The lower incidence of re-infarction, stent thrombosis, AF, and Heart failure among Egyptian patients might be underestimated or due to younger and less risk profile of these patients

\section{In-hospital mortality and status at discharge}

The statistically significant higher in-hospital mortality among Egyptian patients despite their younger age and lower risk profile $(4.65 \%$ vs. $3.50 \%)$ is probably due to the lower rate of primary PCI for reperfusion, the longer delay before first medical contact and the less application of advanced techniques like LV assisting devices and hypothermia.

In an older report, the in-hospital mortality in STEMI patients in different European countries ranged from 3 to $13 \%$. In an American report, the in-hospital mortality for STEMI patients treated with PPCI varied between 3.1 and $6.1 \%$. Egypt is to be compared to the lower range of these old reports, but mortality rate has already improved in these countries.

The mortality rate among Egyptian primary PCI patients reported in this registry $(2.10 \%)$ indicates improvement compared to an older study (Yehia et al. 2010) in which the in-hospital mortality rate among 137 patients treated with primary PCI in one Egyptian tertiary center was $6.57 \%$.

The highest rate of in-hospital mortality among the group of no-reperfusion (18.87\%) indicates that we 
should encourage their earlier presentation because late presentation was the main cause of not offering them any kind of reperfusion.

\section{Medications}

Clopidogrel is the most commonly used ADP receptor blocker even among STEMI patients (91.07\%) while ticagrelor or prasugrel were only used in $7.31 \%$ of Egyptian patients. This might be due either to financial reasons where clopidogrel is available in generic forms, the higher rate of thrombolytic therapy usage where clopidogrel is the default drug, concerns about risk of bleeding or just practice inertia. More potent antiplatelets should be the default drugs used in STEMI patients according to the guidelines [21].

Statins are prescribed for most STEMI patients at discharge (99.77\%), but we do not know which doses are prescribed for such high risk patients. We lack longterm follow-up studies to document the rate of patients' compliance and adherence.

\section{Gaps in guideline implementation in Egypt and implications for quality improvement (Table 4)}

Total ischemic time is much increased due to both patients and system delays. There is an urgent need for public awareness and patient education campaigns to instruct patients with chest pain to seek medical advice as early as possible together with improving the EMS

Table 4 Summary of possible gaps and obstacles and the suggested actions needed to improve STEMI management in Egypt

\begin{tabular}{ll}
\hline $\begin{array}{l}\text { Gaps and obstacles in STEMI } \\
\text { management in Egypt }\end{array}$ & $\begin{array}{l}\text { Actions needed to optimize STEMI } \\
\text { management in Egypt }\end{array}$ \\
\hline $\begin{array}{l}\text { Patients with high prevalence of } \\
\text { risk factors }\end{array}$ & Primary prevention plan \\
$\begin{array}{l}\text { Increased ischemic time and } \\
\text { delayed presentation }\end{array}$ & $\begin{array}{l}\text { Public awareness campaigns and } \\
\text { patient education }\end{array}$ \\
Under use of EMS & $\begin{array}{l}\text { Improving EMS service quantitatively } \\
\text { and qualitatively }\end{array}$ \\
Under use of primary PCl & $\begin{array}{l}\text { Increased health care expenditure } \\
\text { Increase number of PPCl centers }\end{array}$ \\
& $\begin{array}{l}\text { Establish STEMl networks and } \\
\text { protocols }\end{array}$ \\
& $\begin{array}{l}\text { Extend medical insurance } \\
\text { Expand reimbursement to PPCI } \\
\text { centers } \\
\text { Educate and train medical personnel }\end{array}$ \\
Streptokinase is still widely used & $\begin{array}{l}\text { Replace it with TNK } \\
\text { Encourage out of hospital } \\
\text { thrombolytic therapy }\end{array}$ \\
& $\begin{array}{l}\text { Encourage routine PCI post } \\
\text { thrombolysis }\end{array}$ \\
& Encourage more potent antiplatelets \\
Clopidogrel is widely used & Reduce the number of non- \\
righ in-hospital mortality rate & Registries and quality control \\
\hline
\end{tabular}

performance in Egypt. The vast majority of patients with STEMI in Egypt have been self-presented to hospitals rather than via EMS system. We need to improve the performance of EMS in Egypt to become a dependable and efficient mode of STEMI patients transfer.

The number of primary $\mathrm{PCI} /$ per million populations is small due to the limited number of primary PCI centers which, when present, is not connected to a regional network of referring hospitals. There is an obvious unmet need to develop such hub and spoke system in Egypt especially in remote and rural areas. The government should extend the umbrella of medical insurance and its reimbursement to health care centers providing emergency STEMI reperfusion [22-24].

One of the main obstacles that prevent big hospitals at some times to admit patients with STEMI is the lack of empty beds in the CCU. A solution to this problem is patient repatriation after the primary PCI procedure to the local referring hospital. In our study, there was a lower incidence of patients discharged to another hospital, compared to European countries, which is due to absence of repatriation policy.

Pharmaco invasive approach might be a practical way of treating STEMI patients in remote and rural areas, in major cities with heavy traffic and in areas with inefficient EMS system. Thrombolytic agent should be the TNK and not the streptokinase and better given before reaching hospital. Routine coronary angiography with possible PCI to the infarct related artery within 2-24 h after thrombolytic therapy is a guidelines class IA recommendation but in Egypt it is often either neglected or performed after the recommended time window. Such procedure is not reimbursed by the government assuming that the patient has been already reperfused by the thrombolytic therapy [25-29].

\section{Limitations of this study}

Despite every effort to include many centers with diverse activities and geographic locations these centers, and these patients might not represent the actual Egyptian practice especially in some remote and rural areas in Egypt.

\section{Conclusion}

Compared to EU countries, Egyptian STEMI patients were younger, more frequently current smokers and diabetics, and had longer time between symptoms onset and first medical contact with more self-presentation rather than EMS presentation. Thrombolytic therapy is still a common reperfusion therapy in Egypt while primary PCI was offered to half of the patients. In-hospital mortality was significantly higher in Egypt and was highest among no reperfusion patients and lowest among PPCI patients. DAPT and statins at discharge were adequately following guideline recommendations. 


\section{Abbreviations}

STEMI: ST elevation myocardial infarction; ESC: European Society of Cardiology; EMS: Emergency medical system; ECG: Electrocardiography; PCI: Percutaneous coronary intervention; EU: European Union; DAPT: Dual antiplatelet therapy; ACE: Angiotensin converting enzyme; MRAs: Mineralo receptor antagonists; PPCI: Primary percutaneous coronary intervention; CVD: Cardiovascular disease; ACCA: ACCA-EAPCI Acute Cardiovascular Care Association; EAPCl: European Association of Percutaneous Cardiovascular Interventions; EORP: EURObservational Research Programme; CCU: Coronary care unit; ICU: Intensive care unit; ER: Emergency room; LVEF: Left ventricular ejection fraction; ARBs: Angiotensin receptor blockers; FMC: First medical contact; NSTEMI: Non ST elevation myocardial infarction; ACS: Acute coronary syndrome

\section{Acknowledgements}

We would like to express our sincere gratitude to all investigators who contributed to this work, Cecile Laroche from the EORP team for the statistical analysis, and to Dr. Ayman Helal from the Egyptian Society of cardiology for administrative assistance in this work.

\section{Authors' contributions}

SS conceptualized the project, reviewed the literature, analyzed the data, and wrote the manuscript. AW, MM, BZ, AB, TA, AR, MoS, ME, YA, GA, Al, MG, KA, MaS, MW, and MY conceptualized the project and collected the data. All authors read and approved the final manuscript.

\section{Funding}

This survey was funded by the ESC. The Egyptian Society of Cardiology was given a grant of $€ 12000$ to help with the implementation of this national Egyptian STEMI database.

\section{Availability of data and materials}

The datasets used and/or analyzed during the current registry are available from the corresponding author on reasonable request.

\section{Ethics approval and consent to participate}

No data were collected before detailed information was given to the patient and a written consent was obtained. The registry was approved by each local Institutional ethical committee as follows: Faculty of Medicine, Mansoura University, in March 2016 (reference number: RP.20.06.71; Faculty of Medicine, Ain Shams University, in March 2016; Faculty of Medicine, AlAzhar University, in April 2016; National Heart Institute in March 2016; Faculty of Medicine, Banha University, in March 2016; Faculty of Medicine, Assiut University, in May 2016; Egyptian Ministry of Health in March 2016; Faculty of Medicine, Tanta University, in March 2016; Faculty of Medicine, Bani Sweif University, in June 2016; Faculty of Medicine, Fayoum University, in August 2016; Faculty of Medicine, Helwan University, in March 2016; and Kasr Alainy Faculty Of Medicine, Cairo University, in March 2016.

\section{Consent for publication}

Not applicable

\section{Competing interests}

The authors declare that they have no competing interests.

\section{Author details}

${ }^{1}$ Cardiology Department, Ain Shams University Hospitals, Ain Shams University, Cairo, Egypt. ${ }^{2}$ Cardiology Department; Mansoura University Hospital, Mansoura Faculty of Medicine, Mansoura, Egypt. ${ }^{3}$ Cardiology Department, Bab Elsheria and Alhosien University Hospitals, Al-Azhar Faculty of Medicine, Cairo, Egypt. ${ }^{4}$ Cardiology Depatrtment, National Heart Institute, Giza, Egypt. ${ }^{5}$ Cardiology Department, Banha University Hospital, Banha Faculty of Medicine, Banha, Egypt. ${ }^{6}$ Cardiology Department, Assiut University Hospitals, Assiut University, Assiut, Egypt. ${ }^{7}$ Cardiology Department, Fayoum General Hospital, Fayoum, Egypt. ${ }^{8}$ Cardiology Department, National Heart Institute, Giza, Egypt. ${ }^{9}$ Cardiology Department, Tanta University Hospital, Tanta University, Tanta, Egypt.

${ }^{10}$ Cardiology Department, Bani Sweif University Hospital, Bani Sweif University, Bani Sweif, Egypt. ${ }^{11}$ Cardiology Department, Fayoum University Hospital, Fayoum University, Fayoum, Egypt. ${ }^{12}$ Cardiology Department, Helwan University Hospital, Helwan University, Badr City, Egypt. ${ }^{13}$ Cardiology Department, Nasr City Insurance Hospital, Cairo, Egypt. ${ }^{14}$ Cardiology Department, Cairo University Hospitals, Kasr Alainy Faculty of Medicine, Cairo, Egypt.
Received: 8 April 2020 Accepted: 10 June 2020

Published online: 01 July 2020

\section{References}

1. WHO STEPwise approach for chronic disease in the Eastern Mediterranean Region. http://www.emro.who.int/ncd/media/excel/disease.xls.

2. Shaheen S, Magdi A, Esmat I, Mohannad A, El-Kilany W (2012) National Heart Institute Acute Coronary Syndrome Registry. Med J Cairo Univ 80(2): $141-149$

3. Abdelmoneim HM et al (2014) Demographics of acute coronary syndrome (ACS) Egyptian patients admitted to Assiut University Hospital: Validation of TIMI and GRACE scores. The Egyptian Journal of Critical Care Medicine 2:3-11

4. Ragy H, Kazamel G, Sleem M, El Tohamy K, Helmy M, Zarif B, Elsayed M, Sleem H, Magdy A, Alabbadi M, El Gendy F (2017) Abd El Ghafar T, Zaki M, Elbakery A, Abass W. Acute Coronary syndrome registry. Life Sci J 14(3):39-44

5. Zeymer U, Danchin N, Kala P, Ferrari R, Maggioni A, Weidinger F (2017) The European Society of Cardiology ACCA-EAPCI Registry on ST elevation myocardial infarction. Eur Heart J 38(3):138-139

6. Alexander T (2016) STEMI in India. Eur Heart J 37(31):2449-2453

7. AlHabib KF, Sulaiman K, Al-Motarreb A, Almahmeed W, Asaad N, Amin H et al (2012) Gulf RACE-2 investigators. Baseline characteristics, management practices, and long-term outcomes of Middle Eastern patients in the Second Gulf Registry of Acute Coronary Events (Gulf RACE-2). Ann Saudi Med 32:9-18

8. AlHabib KF, Sulaiman K, Al Suwaidi J, Almahmeed W, Alsheikh-Ali AA, Amin $\mathrm{H}$ et al (2016) Patient and system-related delays of emergency medical services use in acute ST-elevation myocardial infarction: results from the Third Gulf Registry of Acute Coronary Events (Gulf RACE-3Ps). PLoS One 11(1):e0147385

9. Shahin M, Obeid S, Hamed L et al (2017) Occurrence and impact of time delay to primary percutaneous coronary intervention in patients with STsegment elevation myocardial infarction. Cardiology Research 8(5):190-198

10. Yehia A, Saleh A, Abdel Kader M. Immediate and intermediate-term results of primary percutaneous coronary intervention: a registry of Ain Shams Faculty of Medicine. Thesis submitted for partial fulfillment of master degree in cardiology. Ain Shams University;2011.

11. Kalla K, Christ G, Karnik R, Malzer R, Norman G, Prachar H et al (2006) Vienna STEMI Registry Group. Implementation of guidelines improves the standard of care: the Viennese registry on reperfusion strategies in ST-elevation myocardial infarction (Vienna STEMl registry). Circulation 113:2398-2405

12. Henry TD, Sharkey SW, Burke MN, Chavez IJ, Graham KJ, Henry CR et al (2007) A regional system to provide timely access to percutaneous coronary intervention for ST-elevation myocardial infarction. Circulation 116:721-728

13. Jollis JG, Roettig ML, Aluko AO, Anstrom KJ, Applegate RJ, Babb JD et al (2007) Reperfusion of Acute Myocardial Infarction in North Carolina Emergency Departments (RACE) Investigators. Implementation of a State wide system for coronary reperfusion for ST-segment elevation myocardial infarction. JAMA 298:2371-2380

14. Alexander T, Mehta S, Mullasari A et al (2012) Systems of care for STelevation myocardial infarction in India. Heart 98:15-17

15. Shaheen S, El-Shehaby N, Soliman H (2012) Practice and outcomes of cardiac catheterization in Egypt before the 2011 Revolution: a report from the Ain Shams University and the National Heart Institute Cardiac Cath Lab Registry. Circulation 125(19):94-99

16. Enany B, Shaheen S, Abdelshafee W, Soliman H (2013) National Heart Institute Registry of Coronary Catheter Interventions. Am J Cardiol 111(7):25-26

17. The ACCESS investigators. Steering Committee, Montalescot G, Antepara N, Escobar A, Alam S, Leizorovicz A, Martinez C, Nicolau J, Sobhy M (2011) Management of acute coronary syndromes in developing countries: acute coronary events- a multinational survey of current management strategies. Am Heart J 162(5):852-859

18. Widimsky P, Wijns W, Fajadet J, de Belder M, Knot J, Aaberge L et al (2010) Reperfusion therapy for ST elevation acute myocardial infarction in Europe: description of the current situation in 30 countries. Eur Heart J 31:943-957

19. Kristensen SD, Laut KG, Fajadet J, Kaifoszova Z, Kala P, Di Mario C et al (2014) European Association for Percutaneous Cardiovascular Interventions. Reperfusion therapy for ST elevation acute myocardial infarction 2010/2011: current status in 37 ESC countries. Eur Heart J 35:1957-1970

20. Atlas Writing Group, Timmis A, Townsend N, Gale C, Grobbee R, Maniadakis N, Flather M, Wilkins E, Wright L, Vos R, Bax J, Blum M, Pinto F, Vardas P (2018) European Society of Cardiology: Cardiovascular Disease Statistics 2017. Eur Heart J 39:508-579 
21. Ibanez B, James S, Agewall S et al (2018) 2017 ESC Guidelines for the management of acute myocardial infarction in patients presenting with STsegment elevation. Eur Heart J 39:119-177

22. Ting HH, Rihal CS, Gersh BJ, Haro LH, Bjerke CM, Lennon RJ et al (2007) Regional systems of care to optimize timeliness of reperfusion therapy for ST-elevation myocardial infarction: the Mayo Clinic STEMI Protocol. Circulation 116:729-736

23. Alexander T, Mullasari AS, Narula J (2014) Developing a STEMI system of care for low and middle-income countries: the STEMI-India model. Glob Heart 9:419-423

24. Dharma S, Andriantoro H, Dakota I et al (2015) Organisation of reperfusion therapy for STEMI in a developing country. Open Heart 2:e000240

25. Larson DM, Duval S, Sharkey SW et al (2012) Safety and efficacy of a pharmacoinvasive reperfusion strategy in rural ST-elevation myocardial infarction patients with expected delays due to long-distance transfers. Eur Heart J 33(10):1232-1240

26. Armstrong PW, Gershlick AH, Goldstein P et al (2013) Fibrinolysis or primary PCl in ST-segment elevation myocardial infarction (STREAM investigative team). N Engl J Med 368(15):1379-1387

27. Danchin N, Puymirat E, Steg PG et al (2014) Five-year survival in patients with ST-segment elevation myocardial infarction according to modalities of reperfusion therapy: the French registry on Acute ST-elevation and non-STelevation Myocardial Infarction (FAST-MI) 2005 cohort. Circulation. 129(16): 1629-1636

28. Victor SM, Vijayakumar S, Alexander T et al (2016) Two-year follow-up data from the STEPP-AMI study: a prospective, observational, multicenter study comparing tenecteplase-facilitated PCI vs. primary PCI in Indian patients with STEMI. Indian Heart J 68:169-173

29. Jinatongthai $P$ et al (2017) Comparative efficacy and safety of reperfusion therapy with fibrinolytic agents in STEMI patients. Lancet. 390:747-759

\section{Publisher's Note}

Springer Nature remains neutral with regard to jurisdictional claims in published maps and institutional affiliations.

\section{Submit your manuscript to a SpringerOpen ${ }^{\circ}$ journal and benefit from:}

- Convenient online submission

- Rigorous peer review

- Open access: articles freely available online

- High visibility within the field

- Retaining the copyright to your article

Submit your next manuscript at $\boldsymbol{\nabla}$ springeropen.com 